\title{
MENGKRITISI PEMBERLAKUAN TEORI FIKSI HUKUM (Criticising Enactment Of Law Fiction Theory)
}

\author{
Ali Marwan HSB \\ Kantor Wilayah Kementerian Hukum dan HAM Sumatera Utara \\ Jl. Putri Hijau No. 4 Medan Telp. (061) 4521217 \\ E-mail: ali_marwan@rocketmail.com, No. HP. 085263369503 \\ Tulisan diterima: $1 \overline{8}-4-2016$, revisi: 28-8-2016, disetuju diterbitkan: 26-9-2016
}

\begin{abstract}
In Indonesia, we still find an enactment of law fiction theory in the system of legislation formation. Where everyone is regarded to know the law when it is legislated in the official gazette and one s ignorance on the law or provisions of legislation do not make one free of prosecution (igronantia iuris neminem excusat). It is against the justice values in the society. It is needed effort to erase its enactment, that is the main problem in this research. It uses normative law method. Collecting data by literature and legislation search. The result of this research shows that Indonesia still enact law fiction theory in legislation system. To efface its efficacy can be conducted 2 (two) attempts, both government and society as well, that is publication by lawmaker or legislator and society participation in the establishment of legislation process.
\end{abstract}

Keywords: legislation, efficacy, Legal Fiction

\begin{abstract}
ABSTRAK
Dalam sistem pembentukan peraturan perundang-undangan di Indonesia, masih kita temui adanya pemberlakuan teori fiksi hukum.Dimana semua orang dianggap tahu hukum apabila sudah diundangkan dalam lembaran resmi dan ketidaktahuan seseorang atas hukum atau peraturan perundang-undangan yang berlaku tidak membebaskan seseorang itu dari tuntutan hukum (igronantia iuris neminem excusat). Hal ini tentu bertentangan dengan nilai-nilai keadilan yang ada di masyarakat.Diperlukan upaya-upaya untuk mengikis keberlakuan teori fiksi hukum ini.Hal inilah yang menjadi pokok permasalahan dalam tulisan ini.Metode penelitian yang digunakan adalah metode penelitian hukum normatif dan untuk memperoleh data digunakan studi perundang-undangan dan telaah kepustakaan.Dari hasil penelitian memperlihatkan bahwa teori fiksi hukum masih diberlakukan dalam sistem peraturan perundang-undangan di Indonesia. Untuk mengikis keberlakuan teori fiksi hukum dapat dilakukan 2 (dua) upaya baik dari pemerintah maupun dari masyarakat, yaitu publikasi oleh lembaga pembentuk peraturan perundang-undangan dan partisipasi aktif dari masyarakat dalam proses pembentukan peraturan perundang-undangan tersebut.
\end{abstract}

\section{Kata Kunci: Mengkritisi, Keberlakuan, Fiksi Hukum}

\section{PENDAHULUAN}

Suatu hari, seorang Kepala Keluarga di Dusun Camar Bulan, Desa Temajuk, Kecamatan Paloh, Kabupaten Sambasa, Kalimantan Barat - dusun terluar di perbatasan Indonesia dan Malaysia mendapat problem. Seperti biasa, ia bangun pagi hari dan segera pergi ke ladangnya yang subur di pinggir hutan. Ia bekerja dengan giat seharian itu, demi menafkahi istri dan kedua balitanya. Hingga selepas zuhur, dua orang berseragam menangkap dan membawanya ke tahanan.Warga dusun terluar di Indonesia itu kaget karena dituduh telah terlibat pembalakan liar (illegal logging).
Ia tak mengerti apa maksud penegak hukum lokal yang menahannya dan hanya pasrah ketika dijelaskan bahwa perbuatannya membuka ladang dengan membabat hutan dilarang peraturan. Warga dusun perbatasan ini sama sekali buta hukum(Atmaja, http://www.riaupos.com/857opini-menggugat-asas-fiksi-hukum-.html, diakses 15 Desember 2013).

Ini adalah sebuah contoh kisah - walaupun hanya kisah rekaan - mengenai pemberlakuan teori fiksi hukum di Indonesia. Kisah ini tidak tertutup kemungkinan akan terjadi mengingat wilayah Indonesia yang sangat luas. 
Pemberlakuan teori fiksi hukum di Indonesia dapat dilihat dalam semua jenjang peraturan perundang-undangan. Hal ini diatur dalam Pasal 81 Undang-Undang Nomor 12 Tahun 2011 tentang Pembentukan Peraturan Perundangundangan yang menyatakan: "agar setiap orang mengetahuinya, peraturan perundang-undangan harus diundangkan dengan menempatkannya dalam:

1. Lembaran Negara Republik Indonesia;

2. Tambahan Lembaran Negara Republik Indonesia;

3. Berita Negara Republik Indonesia;

4. Tambahan Berita Negara Republik Indonesia;

5. Lembaran Daerah;

6. Tambahan Lembaran Daerah; atau

7. Berita Daerah.

Artinya, dengan diundangkannya peraturan perundang-undangandalam lembaran resmi sebagaimana dimaksud dalam ketentuan ini, setiap orang dianggap telah mengetahuinya.

Teori fiksi hukum beranggapan bahwa begitu suatu norma hukum diberlakukan, maka pada saat itu pula setiap orang dianggap tahu hukum. Ketidaktahuan seseorang akan hukum tidak dapat membebaskan seseorang itu dari tuntutan hukum (Jimly Asshiddiqie, Makalah, 2008) yang dalam Bahasa Latin disebut igronantia iuris neminem excusat (Indrati, 2007: 152). Menurut H.A.S Natabaya, sebagaimana dikutip Surono (2013: 119) bahwa paradigma dan doktrin berpikir yang melandaskan teori fiksi hukum lazim dalam negara yang menganut sistem civil law.

BerkaitandenganteorifiksihukumMahkamah Agung juga telah beberapa mengeluarkan putusan yaitu Putusan No. 77/Kr/1953, Putusan No. 77 K/ Kr/1961 dan Putusan No. 645 K/Sip/1975, serta dalam putusan Nomor $2066 \mathrm{~K} / \mathrm{Pid}$.Sus/2010.Di manadalamputusan-putusanini,MahkamahAgung memutuskan bahwa ketidaktahuan seseorang terhadap hukum atau undang-undang bukan alasan pemaaf (http://www.hukumonline.com/ berita/baca/lt4dc100992a35a/ketidaktahuanundangundang-tak-dapat-dibenarkan, diakses 16 Desember 2013).

Hal ini tentu bertentangan dengan rasa keadilan yang ada dalam masyarakat. Bagaimana mungkin seseorang yang tidak mengetahui suatu aturan dihukum karena melanggar aturan yang tidak diketahuinya?Padahal seyogianya, suatu peraturan perundang-undangan adalah manifestasi dari kehidupan masyarakat yang perlu diatur dalam suatu peraturan perundang-undangan.

Hal inilah yang menjadi tujuan dari tulisan ini yaitu untuk melihat upaya-upaya apa yang harus dilakukan untuk mengikis keberlakuan teori fiksi hukum?

\section{METODE PENELITIAN}

Untuk memperoleh informasi serta penjelasan mengenai segala sesuatu yang berkaitan dengan pokok permasalahan diperlukan suatu pedoman penelitian atau metode penelitian, hal ini dikarenakan dengan menggunakan metode penelitian yang benar akan diperoleh validitas data serta dapat mempermudah dalam melakukan penelitian terhadap suatu masalah.

Penelitian ini dilakukan dengan metode penelitian yuridis normatif atau penelitian hukum kepustakaan yaitu metode atau cara yang digunakan di dalam penelitian hukum yang dilakukan dengan cara meneliti bahan pustaka yang ada(Soekanto dan Mamudji, 2009: 13 14).

Untuk memperoleh data yang diperlukan dalam penelitian, penulis menggunakan teknik:

1. Studi Dokumen;

Studi dokumen dilakukan dengan cara mempelajari dan menelaah berbagai dokumen seperti:

a. Telaah Peraturan Perundang-undangan dan Peraturan lainnya

Setelah mengumpulkan beberapa peraturan perundang-undangan, maka penulis menyeleksi peraturan perundang-undangan yang berkaitan langsung dengan objek penelitian yaitu Undang-Undang Nomor 12 Tahun 2011 tentang Pembentukan Peraturan Perundang-undangan.

b. Telaah Kepustakaan

Langkah pertama yang penulis lakukan adalah mengumpulkan literatur yang berkaitan dengan objek penelitian, kemudian melihat daftar isi yang sesuai dengan objek penelitian.Selanjutnya 


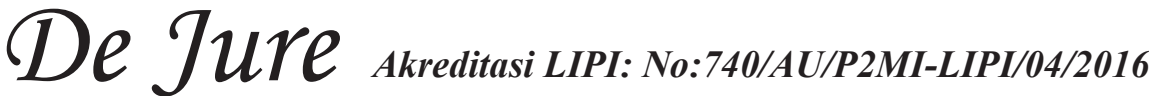

penulis lakukan adalah membaca dan mempelajari literatur yang sudah dikumpulkan serta melakukan seleksi terhadap bahan-bahan yang diperlukan saja sesuai dengan objek penelitian.

\section{PEMBAHASAN}

\section{A. Sekilas Tentang Teori Fiksi Hukum}

Menurut kamus hukum, fiksi atau dalam Bahasa Latin fictio adalah angan-angan, bentuk hukum, kontruksi hukum, bangunan hukum, di samping peraturan perundang-undangan. Van Apeldoorn memberi pendapat, fictie atau fiksi adalah bahwa kita menerima sesuatu yang tidak benar sebagai sesuatu hal yang benar atau dengan kata lain kita menerima apa yang sebenarnya tidak ada sebagai ada atau yang sebenarnya ada sebagai tidak ada(Sokonagoro, dkk, http://sokonagoro. blogspot.com $/ 2008 / 04 / \mathrm{menggali}-\mathrm{makna}$ peristilahan-hukum-dalam.html? $\mathrm{m}=1$, diakses 15 Desember 2013). Fiksi hukum menyatakan bahwa "setiap orang dianggap tahun akan undangundang". Hal ini didasarkan pada satu alasan, bahwa manusiamempunyaikepentingan sejak lahir sampai mati.Setiap kepentingan manusia tersebut selalu diancam oleh bahaya di sekelilingnya.Oleh karena itu manusia memerlukan perlindungan kepentingan, yang dipenuhi oleh berbagai kaidah sosial yang salah satunya adalah kaidah hukum. Karena kaidah hukum melindungi kepentingan manusia, maka harus dipatuhi manusia lainnya. Sehingga timbul kesadaran untuk mematuhi peraturan hukum, supaya kepentingannya sendiri terlindungi(Surono, 2013: 119).

Dalam Ilmu Hukum, teori fiksi hukum menyatakan bahwa diundangkannya sebuah peraturan perundang-undangan oleh instansi yang berwenangmengandaikansemuaorangmengetahui peraturan tersebut. Dengan kata lain tidak ada alasan bagi pelanggar hukum untuk menyangkal dari tuduhan pelanggaran dengan alasan tidak mengetahui hukum atau peraturannya(Rahman, http://strife-hukumindonesia.blogspot. com/2008_08_01_archive.html, diakses 15 Desember 2013) yang dalam bahasa belanda dikenal dengan adagium "ieder een wordt geacht de wet te kennen" (Ranggawidjaja, 1998; 91).
Teori fiksi hukum mengasumsikan bahwa pengundangan peraturan mempunyai kekuatan mengikat, mengikat setiap orang untuk mengakui eksistensi peraturan tersebut. Dengan demikian, pengundangan peraturan tersebut tidak memerdulikan apakah masyarakat akan mampu mengakses peraturan tersebut atau tidak, apakah masyarakat akan menerima peraturan tersebut atau tidak. Disinilah muncul kelemahan dari teori fiksi hukum, Pemerintah dapat berbuat sewenangwenang pada masyarakatyang dianggap melanggar aturan hukum dan menyampingkan ketidaktahuan masyarakat atas hukum atau peraturan yang harus ditaati (Rahman, http://strife-hukumindonesia. blogspot.com/2008_08_01_archive.html, diakses 15 Desember 2013).

Menurut, Saefuddin bahwa Teori/Asas Fiksi Hukum diperlukan untuk mengantisipasi ketika peraturan perundang-undangan itu diberlakukan terhadap seseorang yang belum mengetahui adanya suatu peraturan perundang-undangan. Tanpa adanya teori/asas fiksi hukum kemungkinan banyak orang yang akan lolos dari jeratan peraturan perundang-undangan (Saefuddin, 2009: 80).

Jadi fiksi perundang-undangan itu sebenarnya bukanlah tidak dapat dibuang. Akan tetapi bahwa ia sering dipakai terutama dapat dipahami dari sudut hasrat pembentuk undangundang untuk memperolehperumusan yang singkat. Adakalanya juga pembentuk undangundang memakai fiksi, padahal pemakaian fiksi itu dapat dihindarinya.Hukum yang tugasnya mengatur kehidupan masyarakat sebenarnya tidak boleh dijelmakan dalam peraturan-peraturan yang dalamperumusannya jelas bertentangan dengan kenyataan. Adalah kewajiban ajaran hukum untuk sebanyak mungkin mengeluarkan fiksi dari perundang-undangan, dengan kata lain, mempersiapkan peraturan-peraturan yang sederhana (Rahman, Publisitas, Fiksi Hukum dan Keadilan, http://strife-hukumindonesia. blogspot.com/2008_08_01_archive.html, diakses 15 Desember 2013 Pukul 15.37 WIB).

Sebenarnya pemakaian fiksi hukum dalam perundang-undangan dan dalam ajaran hukum menyebabkan kerugian yang besar.Pemakaian fiksi hukum tersebut mengakibatkan kebiasaan para ahli hukum memakai fiksi dengan tidak semestinya. Karena dalam Undang-undang dan dalam literatur yang bersifat ilmu pengetahuan hukum, ahli hukum seringkali mempergunakan 
fiksi.Akhirnya ahli hukum, karena terbiasa dengan penggunaan fiksi hukum tersebut, menjadi sangat lancar mempergunakannya.Itulah sebabnya, fiksi hukum memegang peranan juga dalam pengadilan dan terkadang memegang peran yang sangat berbahaya.Untuk hakim, fiksi adalah alat yang memikat, karena fiksi memberikan hakim kemampuan untuk mencapai suatu keadaan yang diinginkannya (Surono, 2013: 112).

\section{B. Asas Pembentukan Peraturan Perundang- Undangan}

Dalam Pasal 5 UU No. 12 Tahun 2011 disebutkan asas dalam pembentukan peraturan perundang-undangan ada beberapa asas yang harus dipenuhi dalam pembentukan peraturan perundang-undangan agar peraturan perundangundangan yang dihasilkan adalah peraturan perundang-undangan yang baik. Asas-asas tersebut yaitu: (a) kejelasan tujuan, (b) kelembagaan atau pejabat pembentuk yang tepat; (c) kesesuaian antara jenis, hierarki dan materi muatan; (d) dapat dilaksanakan; (e) kedayagunaan dan kehasilgunaan, (f) kejelasan rumusana; dan(g) keterbukaan.

Asas kejelasan rumusan adalah bahwa setiap pembentukan peraturan perundang-undangan harus mempunyai tujuan yang jelas yang hendak dicapai.Asas ini bertujuan agar peraturan perundang-undangan yang dibentuk tidak menjadi huruf mati karena tidak ada tujuan yang hendak dicapai.

Asas kelembagaan atau pejabat pembentuk yang tepat adalah bahwa setiap jenis peraturan perundang-undangan harus dibuat oleh lembaga negara atau pejabat pembentuk peraturan perundang-undangan yang berwenang. Peraturan perundang-undangan tersebut dapat dibatalkan atau batal demi hukum apabila dibuat oleh lembaga negara atau pejabat yang tidak berwenang.

Asas kesesuaian antara jenis,hierarki, dan materi muatan adalah bahwa dalamPembentukan Peraturan Perundang-undangan harus benar-benar memperhatikan materi muatan yang tepat sesuai dengan jenis dan hierarki Peraturan Perundangundangan.

Asas dapat dilaksanakan adalah bahwa setiap Pembentukan Peraturan Perundang-undangan harus memperhitungkan efektivitas Peraturan Perundangundangan tersebut di dalam masyarakat, baik secara filosofis, sosiologis, maupun yuridis.
Asas kedayagunaan dan kehasilgunaan" adalahbahwa setiapPeraturan Perundangundangan dibuat karena memang benar-benar dibutuhkan dan bermanfaat dalam mengatur kehidupan bermasyarakat, berbangsa, dan bernegara.

Asas kejelasan rumusan adalah bahwa setiap Peraturan Perundang-undangan harus memenuhi persyaratan teknis penyusunan Peraturan Perundang-undangan, sistematika, pilihan kata atau istilah, serta bahasa hukum yang jelas dan mudah dimengerti sehingga tidak menimbulkan berbagai macam interpretasi dalam pelaksanaannya.

Asas keterbukaan adalah bahwa dalam Pembentukan Peraturan Perundang-undangan mulai dari perencanaan, penyusunan, pembahasan, pengesahan atau penetapan, dan pengundangan bersifat transparan dan terbuka. Dengan demikian, seluruh lapisan masyarakat mempunyai kesempatan yang seluas-luasnya untuk memberikan masukan dalam Pembentukan Peraturan Perundang-undangan.

Selain dalam Undang-Undang Nomor 12 Tahun 2011 tentang Pembentukan Peraturan Perundang-undangan, dalam studi dan teori perundang-undangan, paling tidak ada empat syarat bagi pengaturan perundang-undangan yang baik, yaitu persyaratan secara filosofis, sosiologis, yuridis dan teknik perancangan peraturan perundangan-undangan yang baik (Soeprapto, 1998: 196). Adapun teknik perancangan peraturan perundang-undangan yang baik itu harus memenuhi ketepatan struktur, ketepatan perimbangan, ketepatan dasar hukum, ketepatan bahasa (peristilahan), ketepatan dalam pemakaian huruf dan tanda baca (Isrok, 2009: 15).

Selain keempat syarat tersebut, asas-asas pembentukan peraturan negara yang baik juga dikemukakan oleh I.C. van der Vlies dan membagi asas-asas yang formal dan asas-asas material, sebagai berikut (Soeprapto, 2007: 253):

1. Asas-asas yang formal meliputi:

a. Asas tujuan yang jelas (beginsel van duidelijke doelstelling);

b. Asas organ/lembaga tang tepat (beginsel van het juiste orgaan);

c. Asas perlunya pengaturan (het noodzakelijkheids beginsel);

d. Asas dapatnya dilaksanakan (het beginsel van uitvoerbaarheid); 


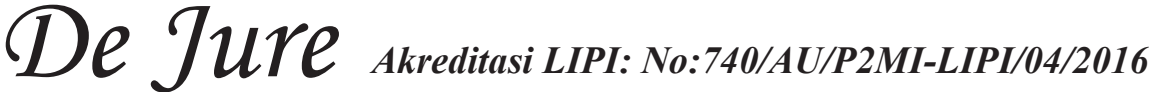

e. Asas konsensus (het beginsel van consensus).

2. Asas-asas yang material meliputi:

a. Asastentangterminologidansistematika yang benar (het beginsel van duidelijke terminologi en duidelijke systematiek);

b. Asas tentang dapat dikenali (het beginsel van de kenbaarheid);

c. Asas perlakuan yang sama dalam hukum (het rechtsgelijkheids beginsel);

d. Asas kepastian hukum (het rechtszekerheidsbeginsel);

e. Asas pelaksanaan hukum sesuai keadaan individual (het beginsel van de individuele rechtsbedeling).

Selain yang dikemukakan oleh Vlies, Purnadi Purbacaraka dan Sorjono Soekanto juga memperkenalkan 6 (enam) asas perundangundangan yaitu (Purbacaraka dan Soekanto, 1979: 15 - 19):

1. Undang-undang tidak berlaku surut;

2. Undang-undang yang dibuar oleh Penguasa yang lebih tinggi mempunyai kedudukan yang lebih tinggi pula;

3. Undang-undang yang bersifat khusus menyampingkan undang-undang yang bersifat umum (lex specialis derogat lex generali);

4. Undang-undang yang berlaku belakangan membatalkan undang-undang yang berlaku terdahulu (lex posteriore derogat lex priori);

5. Undang-undang tidak dapat diganggu gugat; dan

6. Undang-undang sebagai sarana untuk semaksimal mungkin dapat mencapai kesejahteraan spritual dan material bagi masyarakat maupun individu, melalui pembaharuan atau pelestarian.

Dalam perspektif pembentukan peraturan, Montesquieu, dalam karyanya L'esperit des Lois sebagaimana Sumali (2002:124 - 125) mengemukakan sejumlah persyaratan yang harus dipenuhi dalam pembentukan peraturan perundangan-undangan, yakni:

1. Gaya penuturannya hendaknya padat dan sederhana. Ini mengandung arti bahwa pengutaraan dengan menggunakan ungkapan kebesaran dan retorik hanya merupakan tambahan yang menyesatkan dan mubazir;

2. Istilah-istilah yang dipilih hendaknya bersifat mutlak dan relatif, sehingga dengan demikian memperkecil kemungkinan munculnya perbedaan pendapat yang individual;

3. Hukum hendaknya membatasi diri pada halhal yang riil dan aktual dengan menghindari hal-hal yang bersifat metaforis dan hipotetis;

4. Hukum hendaknya tidak dirumuskan dalam bahasa yang tinggi, oleh karena ia ditujukan kepada rakyat yang memiliki tingkat kecerdasan rata-rata, bahasa hukum tidak untuk latihan penggunaan logika melainkan hanya penalaran sederhana yang bisa dipahami oleh orang rata-rata;

5. Hukum hendaknya tidak merancukan pokok masalah dengan pengecualian, pembatasan atau pengubahan, gunakan semua itu jika benar-benar diperlukan;

6. Hukum hendaknya tidak bersifat debatable (argumentatif) adalah bahaya merinci alasanalasan karena hal itu akan menimbulkan konflik;

7. Lebih dari itu semua, pembentuk hukum hendaknya mempertimbangkan masakmasak dan mempunyai manfaat praktis dan hendaknya tidak mengoyahkan sendi-sendi pertimbangan dasar keadilan dan hakekat permasalahan sebab hukum yang lemah tidak perlu dan tidak adil akan membawa seluruh sistem perundang-undangan mendapat citra buruk dan menggoyahkan legitimasi negara.

Lebih lanjut terdapat 8 (delapan) asas atau principle of Legality yang disebutkan oleh Lon L. Fuller dalam bukunya Morality of Law sebagaimana dikutip Satjipto Raharjo (1986: 9192), yaitu:

1. Suatu sistem hukum harus mengandung peraturan-peraturan. Yang dimaksud di sini adalah bahwa ia tidak boleh mengandung sekedar keputusan-keputusan bersifat ad hoc;

2. Peraturan-peraturan yang telah dibuat itu harus diumumkan; 
3. Tidak boleh ada peraturan yang berlaku surut, oleh karena apabila yang demikian itu tidak ditolak, maka peraturan itu tidak bisa dipakai untuk menjadi pedoman tinah laku. Membolehkan pengaturan berlaku surut berarti merusak integritas peraturan yang ditujukan untuk berlaku bagi waktu yang akan datang;

4. Peraturan-peraturan harus disusun dalam rumusan yang bisa dimengerti;

5. Suatu sistem tidak boleh mengandung peraturan-peraturan yang bertentangan satu sama lain;

6. Peraturan-peraturan tidak boleh mengandung tuntutan yang melebihi apa yang dapat dilakukan;

7. Tidak boleh ada kebiasan untuk sering mengubah-rubah peraturan sehingga menyebabkan seorang akan kehilangan orientasi;

8. Harus ada kecocokan antara peraturan yang diundangkan dengan pelaksanaannya seharihari.

\section{Fungsi Pembentukan Peraturan Perundang-Undangan}

Tujuan dibentuknya negara Republik Indonesia sebagaimana termaktub dalam alinea keempat Pembukaan Undang-Undang Dasar Negara Kesatuan Republik Indonesia Tahun 1945 adalah "untuk melindungi segenap bangsa Indonesia dan seluruh tumpah darah Indonesia dan untuk memajukan kesejahteraan umum, mencerdaskan kehidupan bangsa dan ikut melaksanakan ketertiban dunia". Sehingga pembentukan peraturan perundang-undangan tentunya untuk mencapai tujuan dari pembentukan negara tersebut.

Jika dikaitkan dengan salah satu sumber hukum, peraturan perundang-undangan mempunyai fungsi yang sama dengan fungsi hukum. Di mana menurut Sjahran Basah, bahwa ada 5 (lima) fungsi hukum yang disebutnya dengan panca fungsi hukum yaitu: Pertama, Direktif, artinya hukum sebagai pengarah dalam membangun untuk membentuk masyarakat yang hendak dicapai sesuai dengan tujuan kehidupan bernegara. Kedua, Integratif, sebagai pembina kesatuan bangsa. Ketiga, Stabilitatif, sebagai pemelihara dan menjaga keselarasan, keserasian dan keseimbangan dalam kehidupan bernegara dan bermasyarakat. Keempat, Perfektif, sebagai penyempurna, baik terhadap sikap tindak administrasi negara maupun sikap tindak warga negara apabila terjadi pertentangan dalam kehidupan bernegara dan bermasyarakat. Dan kelima, Korektif, sebagai pengoreksi atas sikap tindak, baik administrasi negara maupun warga negara apabila terjadi pertentangan hak dan kewajiban untuk mendapatkan keadilan (Basah, 1992: 13 - 14).

Selain itu, tujuan keadilan dari hukum yang menjadi harapan dari adanya suatu peraturan, hendaknya dikemas dalam suatu mekanisme yang mendukung hakekat keadilan itu sendiri. Hukum harus memastikan bahwa suatu peraturan perundang-undangan tidak hanya seonggok kertas tak bernyali, akan tetapi hukum harus memastikan bahwa suatu peraturan dapat diimplementasikan, tanpa terkecuali (Surono, 2013: 107-108).

Dalam negara hukum yang modern, menurut A. Hamid S. Attamimi, peraturan perundangundangan mempunyai fungsi sebagai berikut (Siallagan dan Yusdiansyah, 2008: 38):

1. Memberikan bentuk pada endapan-endapan nilai-nilai dan norma-norma yang berlaku dan hidup dalam masyarakat;

2. Produk fungsi negara di bidang pengaturan; dan

3. Metode dan instrumen ampuh yang tersedia untuk mengatur dan mengarahkan kehidupan masyarakat menuju cita-cita yang diharapkan.

Fungsi peraturan perundang-undangan sebagai metode dan instrumen ampuh untuk mengatur dan mengarahkan kehidupan masyarakat menuju cita-cita yang diharapkan yaitu untuk melindungi segenap bangsa Indonesia, tentunya bertentangan dengan pemberlakuan teori fiksi hukum. Di mana peraturan perundang-undangan yang dibentuk untuk melindungi segenap bangsa Indonesia justru dinyatakan tetap berlaku kalaupun mereka tidak mengetahui adanya peraturan perundang-undangan yang dibentuk berdasarkan teori fiksi hukum. Seyogianya, bahwa dalam negara hukum modern sekarang ini bahwa harus ada upaya untuk mengikis pemberlakuan teori fiksi hukum. 


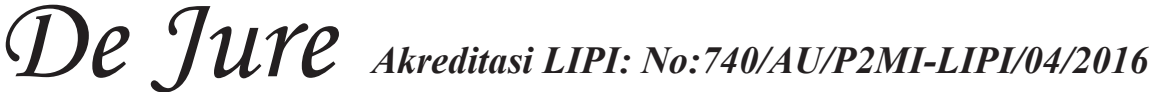

\section{Upaya Mengikis Keberlakuan Teori Fiksi Hukum}

\section{Penyebarluasan Peraturan Perundang- Undangan}

Dalam penjelasan Pasal 88 ayat (1) Undang-Undang Nomor 12 Tahun 2011 tentang Pembentukan Peraturan Perundang-undangan disebutkan bahwa yang dimaksud penyebarluasan adalah kegiatan menyampaikan informasi kepada masyarakat mengenai Prolegnas, Rancangan Undang-Undang yang sedang disusun, dibahas dan telah diundangkan agar masyarakat dapat memberikan masukan atau tanggapan terhadap peraturan perundang-undangan tersebut atau memahami peraturan perundang-undangan yang telah diundangkan. Penyebarluasan Peraturan Perundang-undangan tersebut dilakukan, misalnya melalui media elektronik dan/atau media cetak.

Dalam Undang-Undang Nomor 12 Tahun 2011 tentang Pembentukan Peraturan Perundangundanganproses penyebarluasan merupakan proses yang terpisah dari proses pembentukan peraturan perundang-undangan berbeda dengan pengaturan dalam Undang-Undang Nomor 10 Tahun 2004 tentang Pembentukan Peraturan Perundang-undangan. Dalam pasal 1 angka 2 Undang-Undang Nomor 10 Tahun 2004 tentang Peraturan Perundang-undangan disebutkan bahwa "pembentukan peraturan perundang-undangan adalah proses pembuatan peraturan peraturan perundang-undangan yang pada dasarnya dimulai dari perencanaan, persiapan, teknik penyusunan, perumusan, pembahasan, pengesahan, pengundangan dan penyebarluasan.

Tetapi hal ini mendapat kritikan dari Maria Farida Indrati Soeprapto, yang mengatakan bahwa pemakaian istilah penyebarluasan adalah tidak tepat, oleh karena penyebarluasan (sosialisasi) selama ini dilakukan setelah suatu peraturan perundang-undangan selesai dibentuk, artinya setelah disahkan atau ditetapkan dan diundangkan. Dengan demikian memasukkan kata penyebarluasan dapat berakibat peraturan perundang-undangan tersebut dianggap belum selesai proses pembentukannya, apabila seluruh masyarakat di Indonesia belum mengetahui keberadaan peraturan perundang-undangan tersebut (Soeprapto, 2007: 12).

Kemudian dalam Undang-Undang Nomor 12 Tahun 2011 tentang Pembentukan Peraturan Per- undang-undangan, proses penyebarluasan bukan lagi masuk sebagai proses pembentukan peraturan perundang-undangan dengan digantinya pengertian pembentukan peraturan perundang-undangan dalam Pasal 1 angka 1 menjadi pembuatan peraturan perundang-undangan yang mencakup tahap perencanaan, penyusunan, pembahasan, pengesahan atau penetapan dan pengundangan.

Ketentuan mengenai penyebarluasan peraturan peraturan perundang-undangan diatur dalam Pasal 88 sampai dengan Pasal 95 Undang-Undang Nomr 12 Tahun 2011 tentang pembentukan Peraturan Perundang-undangan. Penyebarluasan undang-undang dilakukan oleh Dewan Perwakilan Rakyat dan Pemerintah sejak penyusunan Prolegnas, penyusunan Rancangan undang-undang, pembahasan Rancangan undang-undang hingga pengundangan undangundang.Penyebarluasan undang-undang dapat juga dilakukan oleh Dewan Perwakilan Daerah khusus untuk undang-undang yang berkaitan dengan fungsi Dewan Perwakilan Daerah.Untuk penyebarluasa peraturan daerah baik peraturan daerah Provinsi maupun peraturan daerah kabupaten/kota dilakukan oleh Dewan Perwakilan Rakyat Daerah dan Pemerintah Provinsi atau Kabupaten/Kota.

Ketentuan tentang penyebarluasan peraturan perundang-undangan dalam Undang-Undang Nomor 12 Tahun 2011 ini dilakukan untuk lebih memperbaiki mekanisme dalam memberikan informasi dan/atau memperoleh masukan masyarakat serta para pemangku kepentingan dalam proses pembentukan peraturan perundangundangan (Yani, 2013: 91).

Dari ketentuan ini dapat kita lihat bahwa penyebarluasan seharusnya dilakukan mulai dari tahap paling awal yaitu ketika menyusun Program Legislasi baik Program Legislasi Nasional maupun Program Legislasi Daerah. Sudah seharusnya juga masyarakat mengetahui peraturan perundangundangan apa saja yang akan dibentuk untuk masa satu tahun. Sehingga masyarakat dapat menilai peraturan perundang-undangan apa saja yang memang sangat diperlukan dan mendesak dan apa saja yang dapat ditunda. Demikian juga setelah berbentuk rancangan, wajib juga disebarluaskan kepada masyarakat.

Penyebarluasan peraturan perundangundangan disetujui usul DPR yang melihat bahwa penyebarluasan undang-undang dan peraturan 
daerah, semestinya melibatkan 2 (dua) pihak pembentuk undang-undang atau peraturan daerah. Penyebarluasan undang-undang dilakukan oleh DPR dan Pemerintah sejak penyusunan prolegnas, penyusunan RUU, Pembahasan RUU hingga pengundangan undang-undang. Untuk menyebarluaskan Prolegnas dilakukan bersama oleh DPR dan Pemerintah yang dikoordinasikan oleh Badan Legislasi DPR. Kemudian untuk penyerbarluasan RUU yang berasal dari DPR dilaksanakan oleh Komisi/Panitia/badan/Badan Legislasi DPR. Sedangkan penyebarluasan RUU yang berasal dari Presiden dilaksanakan oleh instansi pemrakarsa (Yani, Op. Cit: 90).

Ketentuan yang sama juga berlaku dalam penyebarluasan Perda, di mana penyebarluasan dilakukan oleh DPRD bersama pemerintah daerah sejak penyusunan prolegda, penyusunan Raperda, pembahasan Raperda, hingga pengundangan Raperda. Untuk penyebarluasan Prolegda dilakukan bersama oleh DPRD dan pemerintah daerah yang dikoordinasikan oleh Badan Legislasi Daerah. Kemudian untuk penyebarluasan Raperda yang berasal dari DPRD dilaksanakan oleh alat kelengkapan DPRD. Sedangkan penyebarluasan Raperda yang berasal dari gubernur atau bupati/ walikota dilaksanakan oleh sekretaris daerah (Ibid).

Penyebarluasan undang-undang yang terdapat dalam UU Pembentukan Peraturan Perundang-undangan, selain menyebutkan bahwa penyebarluasan undang-undang dilakukan secara bersama oleh DPR dan Pemerintah, dapat pula melibatkan DPD dalam hal undang-undang tersebut sepanjang berkaitan dengan otonomi daerah, hubungan pusat dan daerah, pembentukan dan pemekaran serta penggabungan daerah, pengelolaan sumber daya alam dan sumber daya ekonomi lainnya, serta yang berkaitan dengan perimbangan keuangan pusat dan daerah. Sementara penyebarluasan perda dilakukan secara bersama oleh DPRD Provinsi atau DPRD kabupaten/kota dengan gubernur atau bupait/ walikota (Ibid: 91).

Adapun naskah peraturan perundangundangan yang disebarluaskan harus merupakan salinan naskah yang telah diundangkan dalam Lembaran Negara Republik Indonesia, Tambahan Lembaran Negara Republik Indonesia, Berita Negara Republik Indonesia, Tambahan Berita Negara Republik Indonesia, Lembaran Daerah,
Tambahan Lembaran Daerah dan Berita Daerah. Ketentuan tentang penyebarluasan dalam UU Pembentukan Peraturan Perundang-undangan ini dilakukan untuk lebih memperbaiki mekanisme dalam memberikan informasi dan/ atau memperoleh masukan masyarakat serta para pemangku kepentingan dalam proses pembentukan peraturan perundang-undangan (Ibid).

Penyebarluasan Peraturan Perundangundangan dapat dilakukan melalui media cetak, media elektronik dan cara lainnya. Penyebarluasan melalui media cetak berupa lembaran lepas maupun himpunan. Sedangkan penyebarluasan melalui media elektronik dilakukan melalui situs web kementerian Hukum dan Hak Asasi Manusia dan dapat diakses melalui website www.djpp. kemenkumham.go.id. Penyebarluasan dapat juga dilakukan dengan tatap muka atau dialog langsung berupa ceramah, workshop/seminar, pertemuan ilmiah, konfrensi pers dan cara lainnya.(Raymon, 2012: 48 - 49).

Penyebarluasan peraturan perundangundangan dapat dilakukan dengan cara sebagai berikut (http://ditjenpp.kemenkumham.go.id/ pengundangan-dan-penyebarluasan.html, diakses 18 April 2016 Pukul 09.19 WIB):

1. Penyebarluasan peraturan perundangundangan dapat dilakukan melalui media cetak, media elektronik, dan cara lainnya.

2. Penyebarluasan peraturan perundangundangan melalui media cetak berupa lembaran lepas maupun himpunan.

3. Penyebarluasan Lembaran Negara Republik Indonesia dalam bentuk lembaran lepas yang dilakukan oleh Menteri Hukum dan Hak Asasi Manusia dilaksanakan oleh Direktorat Jenderal Peraturan Perundangundangan untuk disampaikan kepada kementrian/Lembaga yang memprakarsai atau menetapkan peraturan perundangundangan tersebut, dan masyarakat yang membutuhkan.

4. Penyebarluasan Lembaran Negara Republik Indonesia dalam bentuk himpunan yang dilakukan oleh Menteri Hukum dan Hak Asasi Manusia dilaksanakan oleh Direktorat Jenderal Peraturan Perundang-undangan untuk disampaikan kepada Lembaga Negara, Kementerian/Lembaga Pemerintah Non 


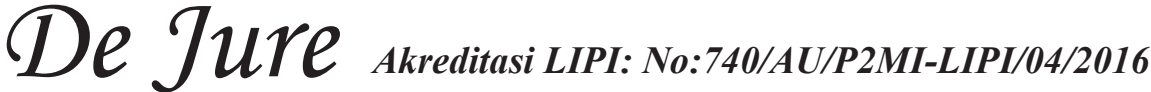

Departemen, Pemerintah Daerah, Dewan Perwakilan Rakyat Daerah, dan pihak terkait.

5. Penyebarluasan melalui media elektronik dilakukan melalui situs web Departemen Hukum dan Hak Asasi Manusia dan dapat diakses melalui website: www.djpp. depkumham.go.id, atau lainnya.

6. Penyebarluasan dengan cara sosialisasi dapat dilakukan dengan tatap muka atau dialog langsung, berupa ceramah workshop/ seminar, pertemuan ilmiah, konfrensi pers, dan cara lainnya.

Untuk mengikis keberlakuan teori fiksi hukum, penyebarluasan peraturan perundangundangan harus lebih dioptimalkan lagi khususnya penyebarluasan melalui media cetak dan melalui cara sosialisasi atau bertatap langsung dengan masyarakat. Penyebarluasan melalui media elektronik khususnya internet masih kurang memadai karena belum semua daerah di Indonesia terjangkau oleh jaringan internet.

Selain itu, agar penyebarluasan peraturan perundang-undangan lebih efektif, setiap kegiatan yangberkaitan dengan kegiatan penyuluhan hukum juga disertai dengan pemberitahuan tentang telah diundangkannya peraturan perundang-undangan yang baru. Baik itu peraturan perundang-undangan pusat maupun peraturan perundang-undangan daerah. Dengan melihat peraturan perundangundangan mana yang lebih bersentuhan langsung dengan masyarakat yang akan disuluh. Sebagai contoh, untuk masyarakat pedesaan perlu dilihat peraturan perundang-undangan mana yang bersentuhan langsung, misalnya Undang-Undang Nomor 16 Tahun 2011 tentang Bantuan Hukum atau Undang-Undang Nomor 23 Tahun 2004 tentang Penghapusan Kekerasan Dalam Rumah Tangga.

Hal ini berarti bahwa untuk lebih mengoptimalkan proses sosialiasi atau penyebarluasan peraturan perundang-undangan menjadi tanggung jawab lembaga pembentuk peraturan perundang-undangan. Untuk peraturan perundang-undang pusat otomatis menjadi tanggung jawab Dewan Perwakilan Rakyat dan Pemerintah melalui semua kementerian yang ada. Juga untuk peraturan perundang-undangan daerah menjadi tugas dari Dewan Perwakilan Rakyat
Daerah dan Pemerintah Daerah melalui Satuan Kerja Perangkat Daerah (SKPD).

\section{Melibatkan Masyarakat Dalam Setiap Tahapan Pembentukan Peraturan Perundang-Undangan}

Peraturan perundang-undangan merupakan suatu sarana untuk mencapai kesejahteraan spritual dan materil bagi masyarakat maupun pribadi, melalui pelestarian ataupun pembaharuan. Artinya supaya pembuat peraturan perundang-undangan tidak sewenang-wenang atau supaya peraturan perundang-undangan tersebut tidak menjadi huruf mati, maka perlu dipenuhi beberapa syarat, yakni antara lain:

1. Keterbukaan dalam proses pembuatan undang-undang;

2. Pemberian hak kepada warga masyarakat untuk mengajukan usul-usul tertentu, melalui cara-cara:

a. Penguasa setempatmengundang mereka yang berminat untuk menghadiri suatu pembicaraan mengenai peraturan tertentu yang akan dibuat:

b. Suatudepartemen tertentu, mengundang organisasi-organisasi tertentu untuk memberikan masukan bagi suatu rancangan peraturan perundangundangan yang sedang disusun;

c. Acara dengar pendapat di Dewan Perwakilan Rakyat(Soekanto, 2013: 13);

Partisipasi masyarakat dalam setiap tahapan pembentukan peraturan perundang-undangan harus benar-benar dilindungi oleh negara dalam pelaksanaannya, agar prinsip-prinsip demokrasi tidak terlanggar oleh penguasa.Sehingga penyediaan ruang publik atau partisipasi masyarakat merupakan tuntutan mutlak dalam sebuah negara demokrasi seperti Indonesia (Indrayanto, Jurnal Legislasi Indonesia Vol. 10 No. 3 - September 2013: 233).

Hal ini berarti bahwa setiap peraturan perundang-undangan yang akan dibentuk harus melibatkan masyarakat. Baik melalui dengar pendapat langsung atau melalui perwakilan organisasi-organisasi masyarakat. Tetapi, hal ini sering tidak dilaksanakan. Tidak ada dengar pendapat, tidak ada pertemuan dengan 
perwakilan organisasi masyarakat, tiba-tiba ada keluar peraturan perundang-undangan.Sehingga masyarakat tidak mengetahui bahwasanya ada peraturan perundang-undangan yang baru.

Keterlibatan masyarakat dalam pembentukan peraturan perundang-undangan juga merupakan implementasi dari salah satu asas pembentukan peraturan perundang-undangan yang diatur dalam Pasal 5 huruf g UU No. 12 Tahun 2011 yaitu asas keterbukaan. Bahwa dalam proses pembentukan peraturan perundang-undangan, masyarakat harus dilibatkan langsung dalam semua tahapan pembentukan peraturan perundang-undangan.

Pembentukanperaturan perundang-undangan pada dasarnya harus melewati beberapa tahapan, mulai dari tahap perencanaan, penyusunan, pembahasan dan pengesahan dan penetapan serta pengundangan.Namun, tahapan-tahapan tersebut tentu dilaksanakan sesuai dengan kebutuhan atau kondisi. Dengan demikian, agar masyarakat mengetahui bahwa akan dibentuk suatu peraturan perundang-undangan yang baru, maka masyarakat sudah seharusnya dilibatkan dalam semua tahapan pembentukan peraturan perundang-undangan.

Dalam hal penyusunan program legislasi nasional/program legislasi daerah, masyarakat seyogianya harus dilibatkan untuk menjaring peraturanperundang-undanganapasajayangpaling dibutuhkan oleh masyarakat sehingga program legislasi nasional/program legislasi daerah sejalan dengan aspirasi yang ada di masyarakat. Dengan mengetahui peraturan perundang-undangan apa saja yang akan dibentuk, masyarakat dapat mengawal agar peraturan perundang-undangan yang sudah diprogramkan dapat dibentuk tepat waktu. Juga dapat mengkritisi jika program yang sudah disusun tidak dapat tercapai tepat pada waktunya.

Ketentuan Pasal 96 ayat (4) Undang-Undang Nomor 12 Tahun 2011 tentang Pembentukan Peraturan Perundang-undangan disebutkan bahwa "untuk memudahkan masyarakat dalam memberikan masukan secara lisan dan/atau tertulis, setiap rancangan peraturan perundangundangan harus dapat diakses dengan mudah oleh masyarakat". Tetapi, pada kenyataannya untuk mendapatkan rancangan peraturan perundangundangan sangat sulit, terutama peraturan perundang-undangan tingkat daerah.

Padahal, partisipasi masyarakat dalam proses pembentukan peraturan perundang- undangan menjadi penting karena, Pertama, menjaring pengetahuan, keahlian atau pengalaman masyarakat sehingga peraturan perundang-undangan benar-benar memenuhi syarat peraturan perundang-undangan yang baik, $K e d u a$, menjamin peraturan perundang-undangan sesuai dengan kenyataan yang hidup dalam masyarakat (politik, ekonomi, sosial dan lainlain); Ketiga, menumbuhkan rasa memiliki (sense of belonging), rasa bertanggungjawab (sense of responsibility dan sense of accountability) atas peraturan perundangan-undangan tersebut (Sirajuddin,dkk, 2007: 187).

Selama ini pelibatan partisipasi masyarakat di dalam pembentukan peraturan perundangundangan terkesanhanya formalitas belaka. Karena itu dalam Undang-Undang Nomor 12 Tahun 2011 tentang Pembentukan Peraturan Perundangundangan berusaha diperbaiki partisipasi masyarakat tersebut dengan memperjelas kategori kelompok kepentingan yang disebut masyarakat, yaitu orang perseorangan atau kelompok/ organisasi masyarakat, kelompok profesi, lembaga swadaya masyarakat dan masyarakat adat. Kemudian setiap kelompok masyarakat yang mempunyai kepentingan atas substansi rancangan peraturan perundang-undangan dapat memberikan masukan atau partisipasinya secara lisan dan/atau rapat dengar pendapat umum, kunjungan kerja, sosialisasi, seminar, lokakarya dan/atau diskusi. Selain itu, perbaikan partisipasi dalam undang-undang Pembentukan Peraturan Perundang-undangan dilakukan agar dapat memberikan kemudahan kepada masyarakat dalam memberikan masukan atau mengakses informasi terkait dengan pembentukan peraturan perundang-undangan (Yani, Op. Cit,: 91 - 92).

Pada dasarnya partisipasi masyarakat bukanlah tujuan akhir. Tujuan sebenarnya adalah memberikan ruang yang lebih luas kepada masyarakat pada umumnya agar mampu memberikan pengaruh yang berarti terhadap proses pemerintahan dalam arti luas (Halim dan Putera, 2013:107). Sehingga secara hukum, hak masyarakat untuk berpartisipasi akan terlanggar jika pembentuk peraturan perundang-undangan tidak membuka ruang untuk itu. Jika hal itu terjadi, sebuah peraturan perundang-undangan dapat dikatakan tidak memenuhi syarat formal peraturan perundang-undangan. Hal ini dapat dijadikan sebagai alasan untuk melakukan uji 


\section{De Jure Akreditusi LIPI: No:740/AU/P2MLLLIPIOA42016}

formal ke Mahkamah Konstitusi dan Mahkamah Agung (Isra, 2010: 292).

Selain pelibatan masyarakat dalam proses pembentukan peraturan perundang-undangan, Menurut Yuliandri, dalam proses pembentukan peraturan perundang-undangan yang berkelanjutan dan partisipatif, perlu dilakukan upaya-upaya yang dapat ditempuh yaitu (1) perlunya perencanaan pembentukan undangundang melalui penyusunan naskah akademis, (2) adanya partisipasi masyarakat atau publik dalam pembentukan peraturan perundang-undangan dan (3) perlu kesesuaian antara materi muatan dengan persyaratan pembentukan peraturan perundangundangan (Yuliandri, 2010: 168).

\section{Masyarakat Harus Pro-Aktif}

Untuk menyebarluaskan peraturan perundang-undangan yang sangat banyak jumlahnya, sangat mustahil hanya dilaksanakan oleh Pemerintah saja baik Pemerintah Pusat maupun Pemerintah Daerah.Semua elemen masyarakat harus turut berperan aktif dalam menyebarluaskan peraturan perundang-undangan yang berlaku di Indonesia.Terutama peraturan perundang-undangan yang berkaitan langsung dengan masyarakat.Masyarakat juga diharapkan berperan aktif mencari dan mengakses peraturan perundang-undangan yang ada.

Dalam Pasal 96 Undang-Undang Nomor 12 Tahun 2011 tentang Pembentukan Peraturan Perundang-undangan diatur mengenai partisipasi masyarakat dalam proses pembentukan peraturan perundang-undangan. Di mana masyarakat diakomodir haknya untuk memberikan masukan secara lisan dan/atau tertulis dalam pembentukan peraturan perundang-undangan yang dapat dilakukan melalui:

a. rapat dengan pendapat umum;

b. kunjungan kerja;

c. sosialisasi; dan/atau

d. seminar, lokakarya dan/atau diskusi.

Tetapi, tidak semua masyarakat akan diundang untuk memberikan pendapat dalam setiap pembentukan peraturan perundangundangan. Hanya orang perseorang atau kelompok orang yang mempunyai kepentingan atas substansi rancangan peraturan perundang-undangan. Tidak mungkin untuk membentuk undang-undang tentang Advokat yang diundang masyarakat adat, tentu yang diundang untuk memberikan pendapat adalah yang berkepentingan langsung yaitu Advokat itu sendiri.

Dengan diberikannya hak untuk memberikan pendapat dalam penyusunan peraturan perundangundangan diharapkan masyarakat dapat berperan aktif sehingga peraturan perundang-undangan yang dibentuk betul-betul peraturan perundangundangan yang sesuai dengan aspirasi masyarakat banyak dan sesuai dengan kebutuhan masyarakat.

Peran aktif masyarakat sangat dibutuhkan dalam proses pembentukan peraturan perundangundangan. Karena dengan wilayah Indonesia yang sangat luas dan suku, budaya dan bahasa yang beraneka ragam, tentu kebutuhan dari tiaptiap masyarakat pasti berbeda-beda tiap-tiap daerah.Perbedaan-perbedaan inilah yang harus ditampung dan diakomodasi dalam suatu peraturan perundang-undangan. Sehingga apabila diadakan dan diundang dalam rapat dengar pendapat umum, kunjungan kerja, sosialisasi, seminar/lokakarya dan/atau diskusi, masyarakat diharapkan turut hadir dan memberikan masukan bagi peraturan perundang-undangan yang akan dibentuk.

Peran pro-aktif dari masyarakat bukan hanya dapat dilakukan pada saat pembentukan peraturan perundang-undangan. Tetapi harus pro-aktif juga untuk melakukan judicial review ke Mahkamah Konstitusi dan Mahkamah Agung jika ada ketentuan-ketentuan dalam peraturan perundangundangan yang bertentangan dengan peraturan perundang-undangan lebih tinggi dan melanggar hak konstitusionalnya sebagai warga negara.

Dalam rangka optimalisasi partisipasi masyarakat yang pro-aktif, Rival G. Ahmad, dkk, mengajukan 8 (delapan) prinsip yaitu (Ahmad, dkk, 109):

1. Adanya kewajiban publikasi yang efektif;

2. Adanyakewajibaninformasidandokumentasi yang sistematis, bebas dan mudah diakses;

3. Adanya jaminan prosedur dan forum yang terbuka dan efektif bagi masyarakat untuk terlibat dalam mengawasi proses sejak perencanaan;

4. Adanya prosedur yang menjamin publik bisa mengajukan RUU selain anggota DPR, DPD dan Pemerinah;

5. Adanya pengaturan yang jelas mengenai dokumen dasar yang wajib tersedia dan 
bebas diakses oleh publik, misalnya naskah akademik dan rancangan peraturan perundang-undangan;

6. Disediakan jaminan banding bagi publik apabila proses pembentukan peraturan perundang-undangan tidak dilakukan secara partisipatif;

7. Adanya pengaturan jangka waktu yang memadai untuk semua proses penyusunan, pembahasan RUU dan diseminasi UU yang telah dilakukan; dan

8. Adanya pertanggungjawaban yang jelas yang memadai bagi pembentuk undang-undang yang dengan sengaja menutup peluang masyarakat untuk berpartisipasi.

\section{KESIMPULAN}

Teori fiksi hukum dalam perkembangan hukum di Indonesia tidak dapat segera dilepaskan atau dibuang begitu saja, mengingat jumlah peraturan perundang-undangan yang diundangkan sangat banyak jumlahnya. Tetapi, pemberlakuan teori fiksi hukum itu harus memenuhi dua syarat yaitu harus ada upaya dari Pemerintah, baik Pemerintah Pusat maupun Pemerintah Daerah untuk mempublikasikan dan mensosialisasikan setiap peraturan perundang-undangan yang dibentuk sesuai dengan yang diatur dalam Undang-Undang Nomor 12 Tahun 2011 tentang Pembentukan Peraturan Perundang-undangan. Syarat yang kedua harus ada upaya dari masyarakat untuk mengetahui dan mengakses peraturan perundang-undangan yang ada.

Hal ini berarti bahwa jika suatu peraturan perundang-undangan tidak dipublikasikan oleh pemerintah, maka teori fiksi tersebut tidak dapat diterapkan bagi orang yang melanggar ketentuan dalam peraturan tersebut. Artinya jika ada seseorang ditangkap karena melanggar hukum dengan alasan bahwa ia tidak mengetahui adanya aturan tersebut. Maka harus dilihat apakah ada upaya dari pemerintah untuk mempublikasikan peraturan perundang-undangan tersebut dan apakah ada upaya dari orang tersebut untuk mencari informasi dan mengakses peraturan perundang-undangan tersebut.Jika kemudian dia terbukti tidak berusaha untuk mencari peraturan perundang-undangan sedangkan pemerintah sudah menyebarluaskan peraturan perundang-undangan tersebut, maka teori fiksi hukum dapat diterapkan kepadanya.Sehingga dia tetap dikenakan hukuman walaupun dia mengaku tidak mengetahui adanya peraturan perundang-undangan tersebut.

Selain itu, mengingat banyaknya jumlah peraturan perundang-undangan yang dibentuk dan diundangkan dalam satu tahun, disarankan agar proses publikasi atau penyebarluasan peraturan perundang-undangan dilakukan secara selektif dengan melihat audiensinya. Penyebarluasan dilakukan kepada masyarakat yang berpotensi melakukan pelanggaran terhadap peraturan perundang-undangan yang dibentuk.Sehingga penyebarluasannya lebih efektif dan efisien.

Untuk mengikis pemberlakuan teori fiksi hukum dalam pembentukan peraturan perundang-undangan di Indonesia seyogianya mengedepankan 2 (dua) hal yaitu publikasi oleh lembaga pembentuk peraturan perundangundangan dan partisipasi aktif dari masyarakat dalam prosesnya. 


\section{DAFTAR KEPUSTAKAAN}

Basah. Sjahran, Perlindungan Hukum terhadap Sikap Tindakan Administrasi Negara, Alumni, Bandung, 1992.

Halim. Hamzah dan Putera. Kemal Redindo Syahrul, Cara Praktis Menyusu \& Merancang Peraturan Daerah; Suatu Kajian Teoretis \& Praktis Disertai Manual, Kencana, Jakarta, 2013.

Indaryanto, Wisnu, Keterlibatan Masyarakat dalam Proses Pembentukan Peraturan Perundangan-undangan, Jurnal Legislasi Indonesia Vol. 10 No. 3 - September 2013, Jakarta, 2013.

Isrok, Korelasi antara Peraturan Daerah (Perda) Bermasalah dengan Tingkat Investasi ke Daerah, Jurnal Hukum Ius Quin Iustum Fakultas Hukum Universitas Islam Indonesia Yogyakarta No. 4 Volume 16, Oktober 2009.

Raharjo. Satjipto, Ilmu Hukum, Alumni, Bandung, 1986.

Raymon, Materi Substansi Peraturan Perundang-undangan, BPSDM Hukum da HAM, Jakarta, 2012.

Saifuddin, Partisipasi Publik dalam Pembentukan Peraturan Perundangundangan, FH UII Press, Yogyakarta, 2009.

Siallagan. Haposan dan Yusdiansyah. Efik, Ilmu Perundang-undangan di Indonesia, UHN Press, Medan, 2008.

Sirajuddin, dkk, Legislative Drafting; Pelembagaan Metode Partisipatif dalam Pembentukan Peraturan Perundangundangan, MCW dan Yappika, Jakarta, 2007.

Soekanto. Soerjono dan Mamudji. Sri, Penelitian Hukum Normatif; Suatu Tinjauan Singkat, Raja Grafindo Persada, Jakarta, 2009.

, Faktor-Faktor yang Mempengaruhi Penegakan Hukum, Rajawali Press, Jakarta, 2013.
Soeprapto, Maria Farida Indrati, IImu Perundang-undangan; Dasar-Dasar dan Pembentukannya, Kanisius, Yogyakarta, 1998.

Ilmu Perundang-Undangan; Jenis, Fungsi dan Materi Muatan, Kanisius, Jakarta, 2007.

Sumali, Reduksi Kekuasaan Eksekutif di Bidang Peraturan Pengganti UU (Perpu), UMM Press, Malang, 2002.

Surono. Agus, Fiksi Hukum dalam Pembuatan Peraturan Perundang-undangan, Universitas Al-Azhar Indonesia, Jakarta, 2013.

Yani. Ahmad, Pembentukan Peraturan Perundang-undangan yang Responsif; Catatan atas UU No.12 Tahun 2011 tentang Pembentukan Peraturan Perundangundangan, Konstitusi Press, Jakarta, 2013.

Yuliandri, Asas-Asas Pembentukan Peraturan Perundang-undangan yang Baik; Gagasan Pembentukan Undang-Undang Berkelanjutan, Rajawali Press, Jakarta, 2010.

\section{Peraturan Perundang-Undangan}

Undang-Undang Nomor 10 Tahun 2004 tentang Pembentukan Peraturan Perundangundangan.

Undang-Undang Nomor 12 Tahun 2011 tentang Pembentukan Peraturan Perundangundangan.

\section{Internet}

Asshiddiqie. Jimly, Peran Advokat Dalam Penegakan Hukum, Jimly.com. Diakses 15 Desember 2013 Pukul 13.25 WIB.

A.P.Edi Atmaja, Menggugat Asas Fiksi Hukum, http://www.riaupos.com/857-opinimenggugat-asas-fiksi-hukum-.html, diakses 15 Desember 2013 Pukul 13.52 WIB.

Ketidaktahuan Undang-Undang tak Dapat Dibenarkan, http://www.hukumonline.com/ berita/baca/lt4dc100992a35a/ketidaktahuanundangundang-tak-dapat-dibenarkan, diakses 16 Desember 2013 Pukul 12.20 WIB. 


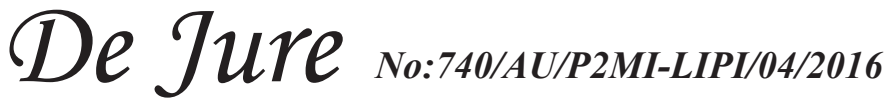

Rahmat Setiabudi Sokonagoro,dkk, Menggali Makna Peristilahan Hukum dalam Bahasa Hukum Indonesia, http://sokonagoro. blogspot.com/2008/04/menggali-maknaperistilahan-hukum-dalam.html? $\mathrm{m}=1$, diakses 15 Desember 2013 Pukul 15.24 WIB.

Yustisia Rahman, Publisitas, Fiksi Hukum dan Keadilan, http://strife-hukumindonesia.blogspot.com/2008 $08 \quad 01$ archive.html, diakses 15 Desember 2013 Pukul 15.37 WIB. 